\title{
Influence of Knowledge Acquisition on Organizational Performance Based on Return on Equity and Return on Assets of State Owned Commercial Enterprises in Kenya
}

\author{
Milkah Kimonda Chebii ${ }^{1 *} \quad$ Prof. Peter Lewa ${ }^{2}$ Dr. James Karimi Ngari ${ }^{2}$ \\ 1.Research Scholar, Chandaria School of Business United States International University-Africa \\ 2.Chandaria School of Business United States International University-Africa, P.O. Box, 14634 - 00800 Nairobi, \\ Kenya
}

\begin{abstract}
Purpose of this study was to analyze the influence of knowledge acquisition on organizational performance based on return on equity and return on assets of state owned commercial enterprises in Kenya. This study was based on explanatory and descriptive research designs since they were more appropriate to test the hypotheses. The target population comprised of 275 members of top management team of 55 commercial state-owned enterprises in Kenya, as at $31^{\text {st }}$ October 2016. The study utilized simple random sampling to select a sample of 268 members of top management team in the 55 commercial state-owned enterprises. Response rate of $71 \%$ was obtained and analytical tests conducted were Pearson correlation coefficients, One Way ANOVA, and Multiple linear regression. The correlation coefficients for return on equity was $(r=-0.052, p=0.481)$ and return on asset was $(r=0.075, p=0.309)$ on knowledge acquisition respectively. Result for One-Way ANOVA on two segments of state owned commercial enterprises was, $\mathrm{F}(14,173)=3.104, p=0.000$. The regression coefficients on return on equity were: unmoderated model; $\beta=-0.957, \mathrm{t}(-1.392), \mathrm{p}>0.05$ and moderated model; $\beta=-4.957, \mathrm{t}$ $(-2.567), \mathrm{p}<0.05$ respectively. While the regression coefficients on return on assets were: unmoderated model; $\beta=0.0002, \mathrm{t}(-0.001), \mathrm{p}=0.999$ and moderated models; $\beta=-0.088, \mathrm{t}(-0.118), \mathrm{p}=0.906$ respectively. The study concludes there is significant influence of knowledge acquisition and organizational performance based on return on equity of state owned commercial enterprises but there is no significant influence of knowledge acquisition on organizational performance based on return on assets of state owned commercial enterprises in Kenya.
\end{abstract}

Keywords: Knowledge acquisition, Return on Assets (ROA), Return on Equity (ROE)

DOI: $10.7176 / \mathrm{EJBM} / 11-3-01$

\section{Introduction}

Intellectual and intangible assets regarded as knowledge are viewed as critical factors in organizational competitiveness. Hence organizations that strive to be successful must acquire adequate knowledge and recognize such knowledge as a critical factor to their competitiveness (Majidi, Radfar \& Toluoei, 2016; Denning, 2006). Serenko, Bontis and Hull (2015) argues that individuals, organizations and countries own intellectual capital that needs to be acquired and applied in order to achieve organisational objectives.

The concept of knowledge acquisition was studied under the Knowledge Management (KM) concept. Davenport (1994) avows Knowledge Management as the process of capturing, distributing, and effectively consuming that knowledge. Knowledge management incorporates the discipline that encourages an integrated approach to identifying, capturing, assessing, retrieving, and sharing organization's information assets that include; databases, documents, policies, procedures, and workers' expertise and experience. This definition was further advanced by King (2009) who viewed Knowledge Management as preparing, organizing and effectively controlling the systems, processes and people in the organization to safeguard knowledge related assets for improvement of organization's performance. Arguably the timing of appreciating KM as a discipline was propitious, as in the 1980s, the fervour for intellectual capital had generated interest for the recognition of information and knowledge as vital assets for any organization' survival. Letonja and Duh (2016) avers that methods of networking, transferring, sharing and converting knowledge are important in any firm performance due to their influence in innovations.

On the dependent variable, Organizational performance has been the most important issue for every organization, be it a profit or non-profit one (Ismael, Yusof \& Davoud, 2010). Thus, organizational performance is one of the most important variables in the management research and arguably the most important indicator of the organizational growth. Ismael et al. (2010) posits that performance can be considered as a set of financial and non-financial indicators that provides information on the level of organizational achievement of results and overall set objectives. Being an important factor, organizational performance can be enhanced when organizations leverage on its intellectual asset whilst preserving such assets from decay, seeks opportunities to enhance decisions, services and products through adding intelligence, increasing value and providing flexibility (Stankosky, 2008). Other arguments propose that knowledge management complements and enhances other organizational initiatives such as; Total Quality Management (TQM), Business Process Re-engineering (BPR) 
and organizational learning as well as providing a new and urgent focus to sustain competitive position (Bhojaraju, 2005).

In Kenya, the principles behind the establishment of state owned commercial enterprises are operational autonomy, flexibility, results-orientation, value for money and greater accountability and transparency that are usually difficult to realize in mainstream government bureaucracy. These entities are distinct from departments of government ministries by virtue of incorporation, operational autonomy, commercial and quasi-commercial orientation and accountability (Government of Kenya, 2013). Therefore, state owned commercial enterprises have a goal of making profit and being sustainable (Government of Kenya, 2013a). However, since their establishment, state owned commercial enterprises have had notable successes, failures and missed opportunities in development. For instance, some of the state owned commercial enterprises have consistently been making profits while others are performing poorly. Noteworthy is the fact that 21 percent of all state owned commercial enterprises made losses in 2011/2012. This represents nearly a quarter of the state owned commercial enterprises (Government of Kenya, 2013b). This calls for the research to determine if knowledge acquisition improved performance.

The extant literature on knowledge management including knowledge acquisition practices are largely extended on the international organizations and private commercial companies hence there exists limited studies that focuses on the influence of knowledge acquisition on performance of state owned enterprises in a developing country such as Kenya. Additionally, knowledge acquisition under knowledge management and organizational performance appears to be parallel in the sense that, the two concepts have been studied as separate constructs by various scholars and practitioners; hence the status of interdependence has not been well appreciated.

Despite conversation of state organs to commercial in order to make profit, $21 \%$ of state owned commercial enterprises made losses in 2011/2012. Some of these enterprises include National Cereals \& Produce Board, (Kshs. 166,713), IDB Capital Limited (Kshs. 9,536), Kenya Industrial Estates Ltd (Kshs. 12,236) and Kenya National Trading Corporation at (Kshs. 29,472). (Government of Kenya, 2013b). This trend is worrying hence the need for urgent attention by the various stakeholders charged with the management of the state owned commercial enterprises in Kenya. Failure to address the problem may lead to a halt in operations of these enterprises, leading to further loss of income to the government and source of livelihoods to various stakeholder $\mathrm{s}$ including employees and suppliers. The question derived from this was, can knowledge acquisition as component of knowledge management improves state owned commercial enterprises organization performance? Purpose of this study was to analyze the influence of knowledge acquisition on organizational performance of state owned commercial enterprises in Kenya based on return on equity and return on assets.

\section{Literature Review}

Theory of Reasoned Action (TRA) was used in this study. Developed by Ajzen and Fishbein (Fishbein and Ajzen, 1975), TRA has been recognized as one of the most influential theories of human behaviour. According to their theory, human behaviour is influenced by the intention to execute that particular behaviour, and the intention forms under the impact of attitude toward the behavior. In other words, a positive attitude toward a behaviour together with a positive subjective norm forms individual's intention to engage in the behaviour, and in turn results in performance.

Theory of Reasoned Action assumes the human being to be rationale and explains that the human behaviour is the determinant of three elements: (1) attitude toward the behaviour, (2) subjective norms, and (3) behaviour intention. Miller (2005), defined these associated factors as "Attitude accounts for the sum of a person's beliefs about a behaviour, with specific weights given to each aspect of that behaviour", the subjective norm consists of the opinions of people in a person's environment and behaviour intention are considered as the combination of both subjective norms and attitudes. The theory showed that these three factors are the predictors for an individual's actual behaviours. This theory explains how a person's behaviour is influenced by one's intention to do something (Fishbein and Ajzen (1975). Consequently, based on this theory and in the context of knowledge acquisition, it is expected that individuals with respect to knowledge may demonstrate more knowledge acquisition if they hold positive attitude towards knowledge sharing. Therefore, it is meaningful to identify the factors that are influential to individuals' attitude towards knowledge acquisition since the knowledge that one acquire and practice informs the behavior. In turn, the behaviour influence the organizational performance. The research was guided by the following conceptual framework. 
Figure 1: Conceptual framework

\section{Independent Variables:}

\section{Dependent Variables:}

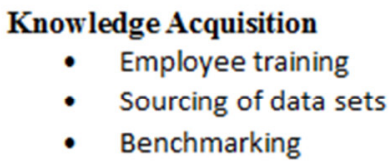

Shu-Hsien, Wu-Chen and Chi-Wen (2008) observed that an organization obtains the required knowledge through connections to networks either within or outside the organization. They consequently argued that communications, interactions and learning within or outside an organization are the components of knowledge acquisition process, and also the way knowledge is acquired. That explains why a company's connections with external networks, along with the competencies and knowledge structure of its employees, are the determinant factors for its capacity to acquire knowledge.

Matin and Sabagh (2015) undertook an investigation of the relationship between knowledge management capabilities and organizational performance in Iranian export companies. The study focused on knowledge management indices, namely knowledge acquisition, knowledge transfer, knowledge protection and knowledge application. The population of study included the entire senior managers of companies that are members of Khorasan Razavi Exporters Union and the sample size was 148. The result of confirmatory factor analysis determined that both research models are estimated significantly. Further, the result of path analysis determined that there is a direct and significant relationship between knowledge acquisition and organizational performance among other factors

Ahmed, Fiaz and Shoaib (2015) carried out a study to identify the effect of knowledge management practices such as knowledge acquisition on organizational performance. From sample of 256 in the banking industry, the result revealed that organizations that encouraged knowledge acquisition processes such as internal exchange of ideas and access to organization's knowledge improved their performance. The study was meant to offer a framework for organizations to put into action knowledge management practices within the firm for improved organizational performance.

Nnabuife, Onwuka and Ojukwu (2015) analysed knowledge management and organizational performance in selected commercial banks in Awka, Anambra State, Nigeria. The study sought to determine examined the extent to which knowledge acquisition affects the performance of an organization. The Pearson correlation utilized to analyse data established a positive relation between knowledge acquisition and organization performance.

Kombo, K'Obonyo and Ogutu (2015) studied knowledge strategy and innovation in manufacturing firms in Kenya. Using a cross sectional survey research design, a stratified sample of 266 out of 655 firms representing twelve sub-sectors of manufacturing sector surveyed was used. The study concluded that higher levels of knowledge strategy in terms of exploration, acquisition and exploitation (usage) would result in higher organizational innovation impacting on overall performance. These researchers clearly indicated the importance of knowledge acquisition in organization performance

\section{Research Methodology}

This study used positivist research philosophy. This study was based on explanatory and descriptive research designs since they were more appropriate in enabling the researcher to test the hypotheses.

The target population for this study comprised of 275 members of top management team of 55 commercial state-owned enterprises in Kenya, as at $31^{\text {st }}$ October 2016. The respondents in each of the organizations comprised of 5 members of top management that is; human resources manager, information technology manager, finance manager, administration manager/corporate communication and marketing/customer service relationships manager

Sample size was obtained by Yamane (1967) sample size formula: total population 275, precision error 0.01 .

$$
\begin{gathered}
n=N /\left\{1+N \varepsilon^{2}\right\} \\
n=275 /\left\{1+275(0.01)^{2}\right\}
\end{gathered}
$$

The study collected data from 268 members of top management team from the 55 commercial state-owned enterprises in Kenya.

The study utilized simple random sampling to select a sample of 268 members of top management team. Response rate of $71 \%$ was obtained and analytical tests conducted were Pearson correlation coefficients, One Way ANOVA, and Multiple linear regression. 


\section{Results and Findings}

The study sought to determine normality of the independent variables. Based on results on Shapiro-Wilk, the knowledge acquisition variable was statistically significant $(\mathrm{p}=0.05)$, this implies that the data deviates from a normally distribution. Multicollinearity was tested by using Pearson correlation coefficient. The test established that there was absence of collinearity since the Pearson correlation for knowledge acquisition was less than 0.8 . There were six variables measuring the knowledge acquisition. To reduce the number of items and develop an appropriate measure for knowledge acquisition. The value of KMO was 0.857 which was greater than 0.5; Bartlett's test had a chi square of 617.641 that was significant at $1 \%$ level. The results for total variance explained for knowledge acquisition extracted only one component that explained $66.095 \%$ of the total variables. The derived factor 'knowledge acquisition' was used in the study.

Correlation analysis was conducted to examine the relationship between knowledge acquisition and organizational performance of state owned commercial enterprises. The correlation coefficients for return on equity and return on asset on knowledge acquisition were $(r=-0.052, p=0.481)$ and $(r=0.075, p=0.309)$ respectively. The correlation coefficient value indicates a weak association implying that no significant relationship exists between knowledge acquisition and organizational performance of state owned commercial enterprises. The study conducted One-Way ANOVA to examine if there were significant differences in mean of knowledge acquisition across two segments of state owned commercial enterprises. The ANOVA test established that there was a statistically significant, $\mathrm{F}(14,173)=3.104, p=0.000$, difference in the mean of knowledge acquisition for pure and strategic commercial state owned enterprises in Kenya.

Multiple regression analysis was conducted for both moderated and unmoderated model in order to establish the effect of knowledge acquisition on organizational performance. Model 1 presents the unmoderated and model 2 presents the moderated. The moderation was age of the firm. In model 1, 2.8\% of the variations in return on equity can be explained by knowledge acquisition (Adjusted $\mathrm{R}^{2}=0.028$ ) and in model $2,18.5 \%$ of the variations in return on equity can be explained by knowledge acquisition (Adjusted $\mathrm{R}^{2}=0.185$ ) as shown in table 1.

Table 1: Model Summary for Knowledge Acquisition on Return on Equity

\begin{tabular}{lllll}
\hline Model & $\mathrm{R}$ & R Square & Adjusted R Square & Std. Error of the Estimate \\
\hline 1 & .243 & .059 & .028 & 7.30958 \\
\hline 2 & .491 & .241 & .185 & 6.69487 \\
\hline
\end{tabular}

The Analysis of Variance (ANOVA) examine if the models significantly predicted return on equity. The study established that model 1 was not a good fit for the data $(\mathrm{F}(5,153)=1.912, \mathrm{p}=0.095)$. Model 2 was statistically significant $(\mathrm{F}(11,147)=4.253, \mathrm{p}=0.000)$ and was a good fit for the data as shown table 2 . Table 2: ANOVA for Knowledge Acquisition on Return on Equity

\begin{tabular}{lllllll}
\hline Model & & Sum of Squares & Df & Mean Square & F & Sig. \\
\hline \multirow{2}{*}{1} & Regression & 510.895 & 5 & 102.179 & 1.912 & .095 \\
\cline { 2 - 7 } & Residual & 8174.773 & 153 & 53.430 & & \\
\cline { 2 - 7 } & Total & 8685.669 & 158 & & 4.253 & .000 \\
\hline 2 & Regression & 2096.938 & 11 & 190.631 & & \\
\cline { 2 - 7 } & Residual & 6588.730 & 147 & 44.821 & & \\
\cline { 2 - 7 } & Total & 8685.669 & 158 & & & \\
\end{tabular}

The coefficient table provides us with necessary information to predict return on equity values from knowledge acquisition values. The regression coefficients for model 1 was statistically insignificant, $\beta=-0.957, \mathrm{t}$ $(-1.392), p>0.05$, implying that knowledge acquisition was insignificant in predicting the values of return on equity. Model 2, was statistically significant, $\beta=-4.957, \mathrm{t}(-2.567), \mathrm{p}<0.05$, indicating that the knowledge acquisition was statistically significant in predicting return on equity if moderated by age of the firm (table 3 ).

Table 3: Regression Coefficients for Knowledge Acquisition on Return on Equity

\begin{tabular}{|c|c|c|c|c|c|c|}
\hline \multirow[t]{2}{*}{ Model } & & \multicolumn{2}{|c|}{ Unstandardized Coefficients } & \multirow{2}{*}{$\begin{array}{l}\text { Standardized Coefficients } \\
\text { Beta }\end{array}$} & \multirow[t]{2}{*}{$\mathrm{T}$} & \multirow[t]{2}{*}{ Sig. } \\
\hline & & $\mathrm{B}$ & Std. Error & & & \\
\hline 1 & (Constant) & -4.296 & 3.008 & & -1.428 & 0.155 \\
\hline & Knowledge Acquisition & -0.957 & 0.688 & -0.134 & -1.392 & 0.166 \\
\hline 2 & (Constant) & -27.545 & 9.383 & & -2.936 & 0.004 \\
\hline & Knowledge Acquisition & -4.957 & 1.931 & -0.693 & -2.567 & 0.011 \\
\hline
\end{tabular}

The study also conducted a regression analysis for knowledge acquisition on return on asset. In model 1, 1.4\% of the variations in return on asset can be explained by knowledge acquisition $\left(\mathrm{R}^{2}=0.014\right)$. In model $2,2.0 \%$ of the variations in return on asset can be explained by knowledge acquisition $\left(\mathrm{R}^{2}=0.020\right)$ as presented in Table 4 . 
Table 4: Model Summary for Knowledge Acquisition on Return on Asset

\begin{tabular}{lllll}
\hline Model & $\mathrm{R}$ & $\mathrm{R}$ Square & Adjusted R Square & Std. Error of the Estimate \\
\hline 1 & .117 & .014 & -.019 & 2.54864 \\
\hline 2 & .141 & .020 & -.053 & 2.59188 \\
\hline
\end{tabular}

On the Analysis of Variance (ANOVA), Model 1 was statistically insignificant, $F(5,153)=0.423, p=0.832$, and not a good fit for the data. Model 2 had F $(11,147)=0.271, p=0.990$, implying that the model was statistically insignificant and not a good fit for the data (table 5).

Table 5: ANOVA for Knowledge Acquisition on Return on Asset

\begin{tabular}{lllllll}
\hline Model & & Sum of Squares & Df & Mean Square & F & Sig. \\
\hline 1 & Regression & 13.735 & 5 & 2.747 & .423 & .832 \\
& Residual & 993.820 & 153 & 6.496 & & \\
& Total & 1007.555 & 158 & & & .271 \\
\hline 2 & Regression & 20.032 & 11 & 1.821 & .990 \\
& Residual & 987.523 & 147 & 6.718 & & \\
& Total & 1007.555 & 158 & & & \\
\hline
\end{tabular}

From the coefficient table, model 1 was $\beta=0.0002$, t (-0.001), $p=0.999$, implying that knowledge acquisition was statistically insignificant in predicting return on asset. In model $2, \beta=-0.088, \mathrm{t}(-0.118), \mathrm{p}=0.906$, the results imply that knowledge acquisition was statistically insignificant in predicting the return on asset (table 6).

Table 6: Coefficients for Knowledge Acquisition on Return on Asset

\begin{tabular}{lllllll}
\hline Model & & \multicolumn{2}{c}{ Unstandardized Coefficients } & Standardized Coefficients & t & Sig. \\
\hline & & $\mathrm{B}$ & Std. Error & Beta & -0.134 & 0.894 \\
\hline 1 & (Constant) & -0.14 & 1.049 & & -0.001 & 0.999 \\
\hline & Knowledge Acquisition & 0.0002 & 0.24 & 0.0 & 0.019 & 0.985 \\
\hline 2 & (Constant) & 0.07 & 3.632 & & -0.118 & 0.906 \\
\hline & Knowledge Acquisition & -0.088 & 0.748 & -0.036 & \\
\hline
\end{tabular}

\section{Discussions, Conclusions and Recommendations}

The findings indicated that Knowledge acquisition was found to significantly influence organizational performance of state owned enterprises in Kenya as measured by return on equity. This implies that the stimulation, assembly, analysis, modelling and authentication of knowledge has a significant and positive influence on the performance of State owned enterprises as measured by Return on Equity but not as measured by Return on Asset.

The results confirm the findings of (Tiwana, 2008) who believes that organizations which subconsciously engage in knowledge acquisition may fail to realize that, in the process, talents and relationships are lost. These results are also in agreement with Ahmed, Fiaz and Shoaib (2015) who did a study on the effect of knowledge management practices on organizational performance. Questionnaires were used to obtain data from 256 respondents in the banking industry, which was then analysed using SPSS software. The findings showed knowledge management activities lead to delivery of quality services, greater customer satisfaction, efficient resource utilization, higher profits and generally enhanced organizational performance.

Martin (2012) conducted a research to examine the knowledge acquisition strategies and company performance in Young High Technology Company in Germany, making use of quantitative and qualitative data. The findings show that four distinct knowledge acquisition strategies differ in their relation to company performance as a result of their configuration of knowledge acquisition activities and the type of knowledge acquired. The researcher established that though knowledge acquisition had a significant influence on performance of high technology companies in Germany.

The findings confirm the research conducted by Nnabuife, Onwuka and Ojukwu (2015) who analyzed knowledge management and organizational performance in selected commercial banks in Awka, Anambra State, Nigeria. The study sought to establish if there is a significant relation between knowledge identification and organizational performance and examined the extent to which knowledge acquisition affects the performance of an organization. The findings show that knowledge acquisition has a positive effect on organizational performance.

The results of the study established that Knowledge acquisition significantly influence organizational performance of state owned enterprises in Kenya as measured by Return on Equity and not by Return on Assets. The study concludes that Knowledge acquisition influences the organizational performance of state owned commercial enterprises in Kenya as measured by Return on Equity.

The regression results showed that for both moderated and unmoderated models, knowledge acquisition did not influence return on assets. The study therefore concludes there is no significant relationship between knowledge acquisition and organizational performance (return on assets) of state owned commercial enterprises 
in Kenya. However, the study found that knowledge acquisition significantly influenced return on equity when age of the firm was used as a moderator but did not significantly affect return on equity in the unmoderated model. The study concluded there is significant relationship between knowledge acquisition and organizational performance (return on equity) of state owned commercial enterprises in Kenya. Since knowledge acquisition influences the organizational performance of state owned commercial enterprises in Kenya based on return on equity, it is thus recommended that an effective knowledge acquisition systems and mechanisms be created to make sure that appropriate knowledge that will enhance organization's performance is identified and acquired.

\section{Reference}

Adan, A. N. (2013). Effects of Knowledge Management Enablers on Organizational Performance: A Case Study of Kenya Revenue Authority. Nairobi: University of Nairobi.

Ajzen, \& Fishbein, M. (1975). Beliefs, attitude, intention and behaviour: An introduction to Theory and research. Boston: Addison-Wesley Publishing Company Reading.

Ahmed, S., Fiaz, M., \& Shoaib, M. (2015). Impact of Knowledge Management Practices on Organization Performance: An Empirical Study of Banking Sector in Pakistan. Journal of Social Sciences, 9(2), 147-167.

Bhojaraju, G. (2005). Knowledge management: Why do we need it for corporate? Malaysian Journal of Library and Information Science, Vol. 10, No.2, 37-50.

Davenport, T. H. (1994). Saving its Soul: Human-Centred Information Management, Harvard Business Review, Mar-Apr. 1994, pp. 119-131.

Denning, S. (2006). Effective storytelling: Strategic business narrative techniques, Strategy \& Leadership, Vol. 34 Issue: 1, pp.42- 48, https://doi.org/10.1108/10878570610637885

Government of Kenya. (2013b). Executive Report on Parastatal Reforms in Kenya. Nairobi: Government of Kenya.

Holsapple, C. W., \& Singh, M. (2001). The knowledge chain model: Activities for competitiveness. Expert Systems with Applications, 20, 77-98.

Ismael, Y., Yusuf, A. and Davoud, M. (2010). A Review paper on Organizational Culture and Performance. Available at www.ijbssnet. Com/Journals/vol.-1-no.3 December-2010/4.Pdf.

Kombo, H., K. K'Obonyo, p., Outu,M. (2015). Knowledge Strategy and Innovation in Manufacturing Firms in Kenya: Iinternational Journal of Scientific Research and Innovative Technology Vol. 2 No. 10

Kuo, T.H. (2011). How to improve organizational performance through learning and knowledge? International Journal of Manpower, 32 (5/6), pp. 581-603.

Letonja, M. \& Duh, M. (2016). Knowledge transfer in family businesses and its effects on the Innovativeness of the next family generation; Knowledge Management \& Research Practice 14: 213-224. doi: $10.1057 / \mathrm{kmrp} .2015 .25$

Matin, E. K., \& Sabagh, P. (2015). Effects of knowledge management capabilities on Organizational performance in Iranian export companies. Mediterranean Journal of Social Sciences. Vol 6 No 2. , ISSN 2039-2117.

Martin, F. (2012). Knowledge Acquisition Strategies and Company Performance in Young High Technology Companies. British Journal of Management, Vol. 23, 325-343.

Majidi K., S., Radfar, R., \& Toluoei, A. (2016). The effect of organizational trust on knowledge Management system achievement. Journal of management development, 27:7-15. Heinemann.

Nnabuife, E.K. \& Onwuka, E.M. (2015). Knowledge management and organizational Performance in selected commercial banks in Awka, Anambra State, Nigeria. IOSR Journal of Business and Management (IOSRJBM) e-ISSN: 2278-487X, p-ISSN:

Ragsdell, G. (2009). Inhibitors and enhancers to knowledge sharing: lessons from the voluntary sector. Journal of Knowledge Management Practice, 10(1), 1-9.

Serenko A., Bontis, N \& Hull, E. (2015). An application of the Knowledge management maturity model; the case of credit unions; Knowledge Management Research \& Practice pp. 1-15. Doi:10.1057/kmrp.2014.37.

Stankosky, M. (2008). Keynote Address to ICICKM (international Conference on Intellectual Capital, Knowledge Management and Organizational Learning), (pp. 9-10).

Tiwana, A. (2008). The knowledge management toolkit: orchestrating IT, strategy and knowledge platforms, 2nd Edition. New Jersey: Prentice Hall.

Yamane, T. (1967). Elementary sampling theory. USA: Prentice-Hall, University of Michigan.

Zwain, A., Teong, L., \& Othman, S. (2012). Knowledge management processes and academic performance in Iraq HE/s: An empirical investigation. International Journal of Academic Research in Business and Social Sciences, Vol. 2(6), 273-293 